\title{
The American Journal of
}

TROPICAL MEDICINE

AND HYGIENE

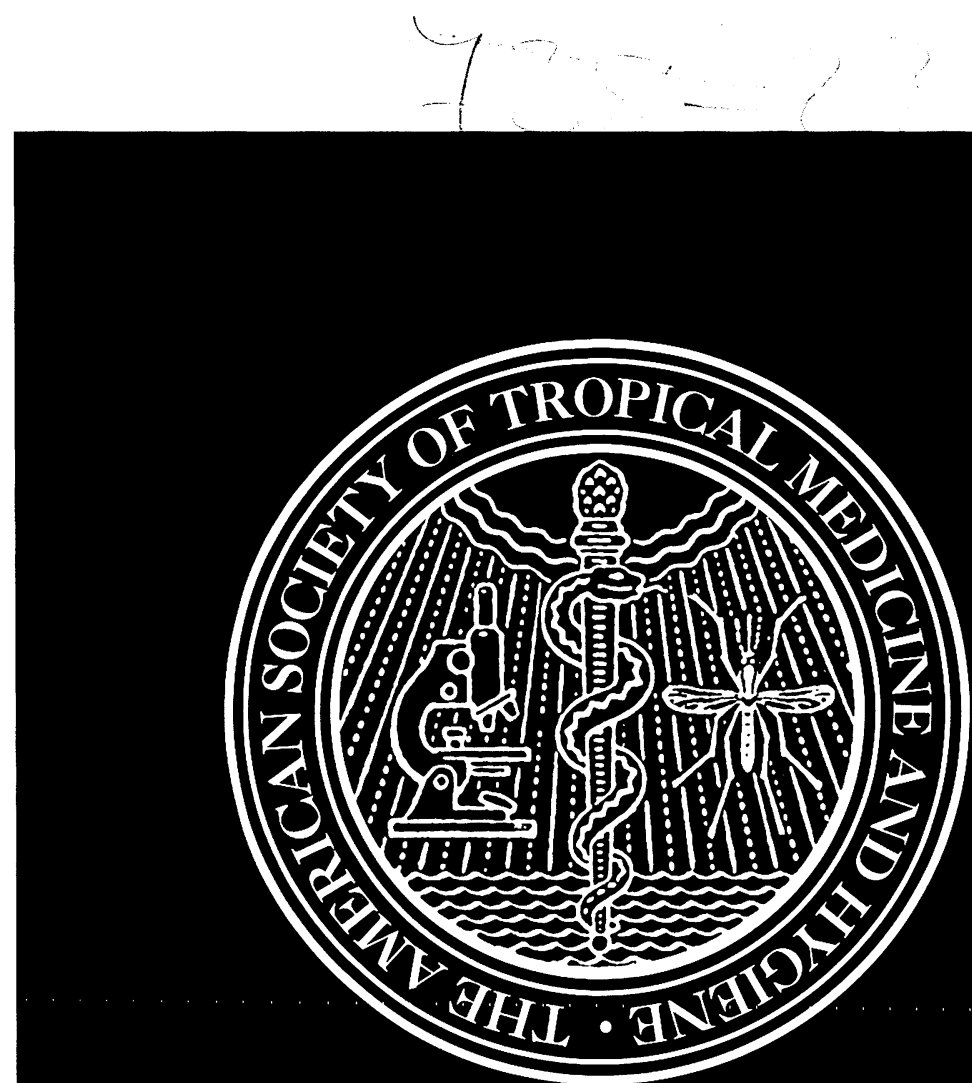

OFFICIAL ORGAN OF

THE AMERICAN SOCIETY OF TROPICAL MEDICINE AND HYGIENE 


\title{
THE AMERICAN JOURNAL OF TROPICAL MEDICINE AND HYGIENE
}

\author{
(ISSN 0002-96.37) \\ Editor; M(WIISON WARRIN \\ 3088 Briatrliff Road, Suite A I Allanta, Georgia 30.329 \\ Telephone (404) 636-3621 FAX: (404) 633-5737 \\ Managing Editor. At.1.1SON KITfIEt.1) \\ Copy/Assistant Editor: ThOMAS Gry(\%aN \\ Associate Editor; MARK L. EBERHARI)
}

\author{
RONALD ANTHONY \\ A. S. BENENSON \\ Donald S. BURKL: \\ Cindrles H. Calishier \\ Allex W. Chelever \\ WILLIAM E. COIIINS \\ DANIEL H. CONNOR
}

Editorial Board

JAMES L. HARIOY
JAMES M. HUCHES
DAVID J. JACOBUS
KARI. JOHNSON
RODNEY C. JUNG
JAY S. KEYSTONE
LLEWIIIYN J. LEGTERS

\author{
STEVEX R. MI:SHNiCK \\ FRANKIIN A. NEVA \\ MetTl: STrand \\ DIANF WAIIACE TAYIOK \\ BRYCE C. WILTON \\ THOMAS YLIII
}

The American Jounal of Tropical Medicine and Hvgiene is published monthly by the American Society of Tropical Medicine and Hygiene and consists of two complete, sequentially numbered volumes each calendar year. The Notice to Contributors maly be found in the first issue of both volumes.

Correspondence concerning business matters, subscriptions. and memberships should be addressed to The American Society of Tropical Medicine and Hygiene, 60 Revere Drive. Suite 500. Northbrook. Illinois 60062; telephone (708) 480-9592. FAX (708) 480-9282.

Manuscripts of articles for publication and books for review should be sent to the Editor

The subscription price for the pair of volumes is $\$ 105.00$ per year in the USA. $\$ 110.00$ per year in Canada and Mexico, and $\$ 170.00$ elsewhere. The price of single copies, when available. is $\$ 17.00$ in the USA and $\$ 18.00$ elsewhere. Second class postage is paid at Northbrook. IL with an additional office at Lawrence. $\mathrm{KS}$.

New subscriptions and renewals are entered to begin with the January issue of the current year. Subscriptions should be renewed promptly: The publisher cannot guarantee to supply back issues on belated renewals.

Change of address. POSTMASTER: Send address changes to the American Society of Tropical Medicine and Hygiene. 60 Revere Drive. Suite 500, Northbrook. Illinois 60)62. Members of the Society should notily the Northbrook oflice of any change in address. All other suhscribers should notify the publisher 60 days in advance. Copies of the Jommal that are undeliverable becausc of an incorrect address will be destroyed. Duplicates of such copies may he obtained (if available) from the publisher at the regular price of single issues.

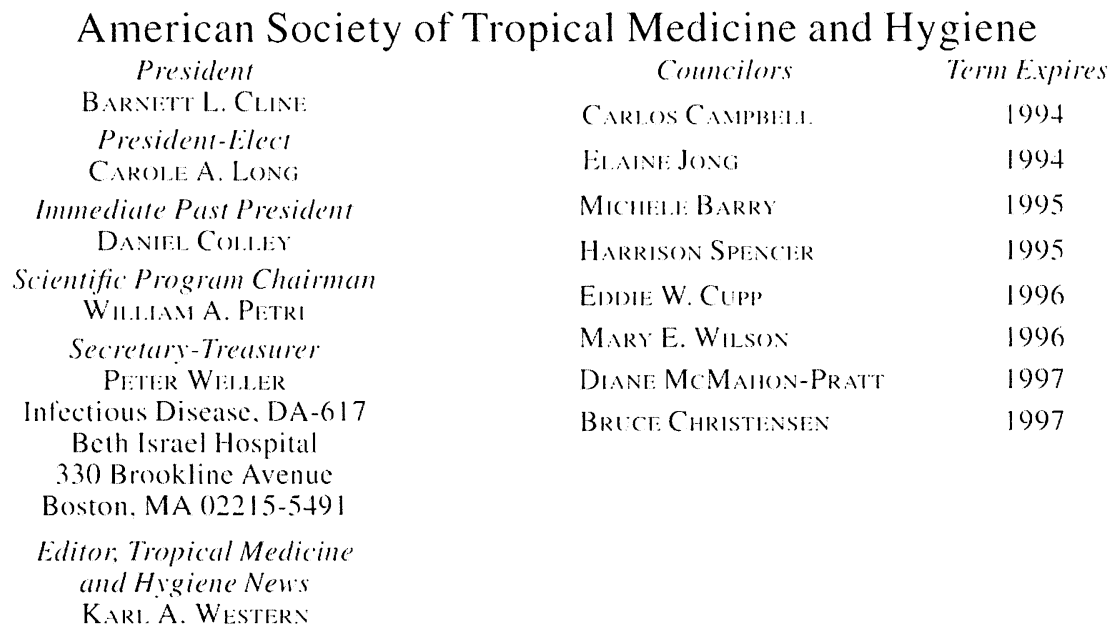

Printed by Allen Press. Inc.: 1041 New Hampshire Street: Lawrence. KS 66044

Statement and opinions expresed in publications of the American Socies of Tropical Sedicine and Hevene or in presentations visen during it regular meetings are those ol the authores and do not necessarily reflect the oflicial position of the American Society of Tropical Medicine and Hy giene. the liditors, or the organizations with which the authors are altiliated. The Editor(s). publisher. and Society disclaim any responsibility or li ability for such material and do not guarantee. Warrant. or endorse any product or service mentioned. nor do they guarantee any claim made by the manuiacturer of such product or service. Official positions of the Society are established only by its Council. 


\section{CONTENTS}

Amoebiasis-180

Filariasis-244

Malaria-123,170, 183, 198.

204, $214,224,233$
Schistosomiasis-162,190

Scrub typhus-149

Shigellosis/Salmonellosis-219
Spotled fever-138

Strongyloidiasis-175

Viral encephalitis-154

\section{EPIDEMIOLOGY}

The Dielmo project: a longitudinal study of natural malaria infection and the mechanisms of protective immunity in a community living in a holoendemic area of Senegal-Jean-Francois Trape, Christophe Rogier, Lassana Konate, Nafissatou Diagne, Hilaire Bouganali, Bruno Canque, Fabrice Legros, Assane Badji, Gora Ndiaye, Papa Ndiaye, Karima Brahimi, Ousmane Faye, Pierre Druilhe, and Luiz Pereira da Silva

Identification of spotted fever group rickettsiae isolated from Dermacentor marginatus and Ixodes ricinus ticks collected in Switzerland-Lorenza Beati, Pierre-Francois Humair, Andre Aeschlimann, and Didier Raoult.

Prevalence of antibodies to rickettsiae in the human population of suburban Bangkok-Daniel Strickman, Panita Tanskul, Chirapa Eamsila, and Daryl J. Kelly

Viruses isolated from mosquitoes collected in Sri Lanka-J. S. M. Peiris, Priyanie H. Amerasinghe, Felix P. Amerasinghe, Charles H. Calisher, L. Parakrama Perera, Chinniah K. Arunagiri, Navaratna B. Munasingha, and S. H. P. Parakrama Karunaratne.

\section{PREVENTION AND CONTROL}

Impact of annual screening and chemotherapy with praziquantel on schistosomiasis japonica on Jishan Island, People's Republic of China-Peter M. Wiest, Guanling Wu, Shaoji Zhong, Stephen T. McGarvey, Jianhua Yuan, Remigio M. Olveda, Pierre A. S. Peters, and G. Richard Olds

\section{CLINICAL STUDIES}

Risk factors for anemia in young children in rural Malawi-Stephen C. Redd, Jack J. Wirima, and Richard W. Steketee

\section{DIAGNOSTIC STUDIES}

Prospective evaluation of enzyme-linked immunosorbent assay and immunoblot methods for the diagnosis of endemic Strongyloides stercoralis infection-John F. Lindo, David J. Conway, Neil S. Atkins, Albert E. Bianco, Ralph D. Robinson, and Donald A. P. Bundy

\section{PATHOLOGY}

Brain abscess due to infection with Entamoeba histolytica-Kenji Ohnishi, Misako Murata, Hirooki Kojima, Nobuhiko Takemura, Tomio Tsuchida, and Hiroshi Tachibana

Immune complexes and nephropathies associated with Plasmodium inui infection in the rhesus monkey-Laila F. Nimri and Norbert H. Lanners

Lack of ultrasonographic evidence for severe hepatosplenic morbidity in schistosomiasis mansoni in Mali-Rudiger Kardorff, Mamadou Traore, Abdoulaye Diarra, Moussa Sacko, Moussa Maiga, Doris Franke, Udo Vester, Ulrike Hansen, Hammar A. Traore, Sahari Fongoro, Helmut Gorgen, Rolf Korte, Bruno Gryseels, Ekkehard Doehring-Schwerdtfeger, and Jochen H. H. Ehrich

\section{DRUG STUDIES}

Sulfated glycoconjugates as disrupters of Plasmodium falciparum crythrocyte rosettes-Stephen $\mathbf{J}$. Rogerson, John C. Reeder, Fadwa AI-Yaman, and Graham V. Brown

Clinical efficacy and pharmacokinetics of micronized halofantrine for the treatment of acute uncomplicated falciparum malaria in nonimmune patients-O. Bouchaud, L. K. Basco, C. Gillotin, F. Gimenez, O. Ramiliarisoa, B. Genissel, E. Bouvet, R. Farinotti, J. Le Bras, and J. P. Coulaud ....

Determination of fifty percent inhibitory concentrations $\left(\mathrm{IC}_{50}\right)$ of antimalarial drugs against Plasmodium falciparum parasites in a serum-free medium-Ayub O. Ofulla, Aloys S. Orago, John I. Githure, James P. Burans, Gladys M. Aleman, Anthony J. Johnson, and Samuel K. Martin ...

Short-course norfloxacin and trimethoprim-sulfamethoxazole treatment of shigellosis and salmonellosis in Egypt-Samir Bassily, Kenneth C. Hyams, Nabil A. El-Masry, Zoheir Farid, Eleanor Cross, August L. Bourgeois, Ezzat Ayad, and Richard G. Hibbs. 


\section{VACCINE STUDIES}

Selection of different strains of Plasmodium falciparum for testing blood-stage vaccines in Aotus nancymai monkeys-William E. Collins, G. Gale Galland, JoAnn S. Sullivan, and Carla L. Morris ....

\section{MASIC/MOLECULAR BIOLOGY}

Sporogonic development of cultured Plasmodium falciparum in six species of laboratory-reared Anopheles mosquitoes-Jefferson A. Vaughan, Bruce H. Noden, and John C. Beier

Kates of acquisition and loss of Wuchereria bancrofti infection in Culex quinquefasciatus-S. Subramanian, A. Manoharan, K. D. Ramaiah, and P. K. Das

.'lassified Advertisement.

Number 1 (July) of Volume 51 was mailed to subscribers on 23 August 1994 


\title{
DIRECT AMPLIFICATION AND DIFFERENTIATION OF PATHOGENIC AND NONPATHOGENIC ENTAMOEBA HISTOLYTICA DNA FROM STOOL SPECIMENS
}

\author{
SYLVIA KATZWINKEL-WLADARSCH, THOMAS LOSCHER, AND HEINZ RINDER \\ Abteilung fur Infektions- und Tropenmedizin der Universitat, Munchen, Germany
}

\begin{abstract}
Discrimination of pathogenic and nonpathogenic Entamoeba histolytica is of great clinical importance. A simple and rapid DNA extraction method that can be used directly with stool specimens was developed without the need for prior cultivation of the parasites. The entire protocol can be performed at room temperature in a $1.5-\mathrm{ml}$ microcentrifuge tube format. There is no DNA precipitation step. The subsequent nested polymerase chain reaction consists of an initial $E$. histolytica-specific amplification, followed by two separate amplifications using two primer pairs specific for pathogenic and nonpathogenic $E$. histolytica, respectively. Amplification products can be verified by restriction endonuclease digests. There is no need for hybridizations or the use of radionucleotides. One trophozoite per milligram of stool sample could be detected and differentiated in a $0.1-\mathrm{g}$ specimen.
\end{abstract}

Amebiasis is an infection of the large intestine caused by the parasitic protozoon Entamoeba histolytica. Generally, a nonpathogenic form is discriminated from a pathogenic one that causes invasive amebiasis. Both forms were first differentiated by characteristic isoenzyme patterns.' It has been suggested that these forms constitute separate species.' Recently, differences on the genomic level have also been described. ${ }^{3-5}$ In this report, those differences in the nucleotide sequences of a small subunit ribosomal RNA gene were used to develop a simple yet sensitive polymerase chain reaction (PCR) technique to detect and differentiate both forms at the same time.

In a first attempt to avoid time-consuming cultivation methods, E. histolytica DNA from stool samples was amplified using freezing with dry ice. an ultrasonic generator, and a $24-\mathrm{hr}$ incubation step. ${ }^{6}$ In an effort to find a method that is fast and simple enough to be performed at room temperature without the need for special equipment, a protocol was developed to detect one trophozoite per milligram in a $0.1 \mathrm{-g}$ stool sample.

\section{MATERIALS AND METHODS}

Entamoeba histolytica trophozoites. Trophozoites of the pathogenic strain HK-9 were grown in axenic culture using TPS- 1 medium as described by Diamond and cryopreserved in liquid nitrogen. ${ }^{7}$
Stool specimens. Stool samples $(0.1 \mathrm{~g})$ from an asymptomatic person without microscopically detectable parasites were mixed with defined numbers of HK-9 trophozoites. Specimens were also obtained from three patients positive for $E$. histolytica cysts on microscopic examination. Cyst concentrations were not determined.

Extractions of DNA. For the comparison of DNA extraction methods, 5000 HK-9 trophozoites were added to $0.1 \mathrm{~g}$ of stool. In a modification of an Echinococcus multilocularis DNA extraction method used with fox feces, ${ }^{7}$ these $0.1 \mathrm{-g}$ stool samples were transferred to $1.5-\mathrm{ml}$ microcentrifuge tubes, $33.3 \mu \mathrm{l}$ of $1 \mathrm{M} \mathrm{KOH}$ and $9.3 \mu \mathrm{l}$ of $1 \mathrm{M}$ DTT were added and mixed thoroughly by stirring with a pipette tip, followed by brief shaking. ${ }^{8}$ After incubation at $65^{\circ} \mathrm{C}$ for 15 min, the samples were neutralized with $4.3 \mu \mathrm{l}$ of $25 \% \mathrm{HCl}$, buffered with $80 \mu \mathrm{l}$ of $2 \mathrm{M}$ Tris$\mathrm{HCl}$ ( $\mathrm{pH} \mathrm{8.3),} \mathrm{and} \mathrm{the} \mathrm{suspension} \mathrm{was} \mathrm{mixed}$ again. The DNA was extracted by shaking with $250 \mu \mathrm{l}$ of phenol:chloroform:isoamyl alcohol (PCI, 25:24:1) saturated with $10 \mathrm{mM}$ Tris (pH 8.0), $1 \mathrm{mM}$ EDTA (Sigma, St. Louis, MO). The phases were separated by a 4-min spin in a microcentrifuge. The aqueous phase was transferred to a new tube and the DNA was further purified by adsorption to $5 \mu \mathrm{l}$ of a silica gel suspension (Geneclean; Bio 101, La Jolla, CA). The DNA was eluted in $38.2 \mu \mathrm{l}$ of water.

For comparison, some 0.1-g stool samples were first washed by suspending them in $700 \mu \mathrm{l}$ 
of $0.9 \% \mathrm{NaCl}$. After centrifugation, the supernatant was discarded. Some samples were PCIextracted three times and others were not extracted. The proteinase $\mathrm{K}$ digestion process used was adopted from a standard protocol. ${ }^{9}$

Nested PCR. Primer construction was based on pathogenic and nonpathogenic sequences from a small subunit ribosomal RNA gene. ${ }^{4}$ For the first PCR, the primer pair EH-1 (TTT GTA TTA GTA CAA A) and EH-2 (GTA (A,G)TA TTG ATA TAC T), which specified a $0.9-\mathrm{kb}$ fragment, was used. For the second (nested) PCR, two different primer pairs that were specific for the pathogenic form (EHP-1: AAT GGC CAA TTC ATT CAA TG and EHP-2: TCT AGA AAC AAT GCT TCT CT) or the nonpathogenic form (EHN-1: AGT GGC CAA TTT ATG TAA GT and EHN-2: TTT AGA AAC AAT GTT TCT TC) were used. All primers were obtained from Genzentrum (Martinsried, Germany). The PCRs were done using a hot start technique in which the 38.2- $\mu$ I DNA extracts or $2 \mu \mathrm{l}$ of the first PCR in $36.2 \mu \mathrm{l}$ water were denatured at $96^{\circ} \mathrm{C}$ for $2 \mathrm{~min}$ after the addition of $1 \mu \mathrm{l}$ each of $50 \mathrm{mM}$ solutions of the primers and two drops of mineral oil. After cooling to $80^{\circ} \mathrm{C}, 9.8 \mu \mathrm{l}$ of a freshly prepared mixture of $5 \mu \mathrm{l}$ of buffer $(100 \mathrm{mM}$ Tris-HCl, $\mathrm{pH} 8.3$, $500 \mathrm{mM} \mathrm{KCl}), 4 \mu \mathrm{l}$ of $50 \mathrm{mM} \mathrm{MgCl}, 0.5 \mu \mathrm{l}$ of dNTP-mix (25 mM each; United States Biochemical Corp., Cleveland, $\mathrm{OH}$ ), and $0.5 \mu \mathrm{l}$ (5 $\mathrm{U} / \mu \mathrm{l}$ ) of $\mathrm{Taq}$ polymerase (Amersham Buchler, Braunschweig, Germany) was added. Fifty cycles were performed with denaturation at $92^{\circ} \mathrm{C}$ for $60 \mathrm{sec}$, annealing at $43^{\circ} \mathrm{C}$ for $60 \mathrm{sec}$ for $\mathrm{EH}$ $1 /-2$ or at $62^{\circ} \mathrm{C}$ for $60 \mathrm{sec}$ for both EHP-1/-2 and EHN-1/-2, and extension at $72^{\circ} \mathrm{c}$ for $90 \mathrm{sec}$. Products were visualized on a $13 \%$ agarose gel containing $0.2 \mu \mathrm{g} / \mathrm{ml}$ of ethidium bromide (Sigma).

Restriction endonuclease digests. Bands excised from the agarose gel were silica gel-purified as described above, eluted in $9.6 \mu \mathrm{l}$ of water, and after the addition of $1.2 \mu$ l of buffer $(\mathrm{Nr}$ 4; New England Biolabs, Beverly, MA), digested with $0.8 \mu \mathrm{l}(10 \mathrm{U} / \mu \mathrm{l})$ of Dra I (Appligene, Illkirch, France) for $60 \mathrm{~min}$ at $37^{\circ} \mathrm{C}$, followed by the addition of $0.4 \mu l(10 \mathrm{U} / \mu \mathrm{l})$ of Sau 96 I (New England Biolabs) and further incubation at the same temperature for another $90 \mathrm{~min}$.

\section{RESULTS}

DNA extraction methods. After $90 \mathrm{~min}$ of digestion with proteinase $\mathrm{K}$, no amplification products could be detected. To generate a rapid protocol, longer incubation times were not considered. In contrast, the alkaline lysis method yielded a $0.9-\mathrm{kb}$ band. In an attempt to simplify the method, it was found that the initial washing step with $0.9 \% \mathrm{NaCl}$ could be omitted without a detectable loss of product. However, the PCI extraction proved to be essential, but no change in yield resulted from repeating it two more times.

Volume of specimens and detection limit. Since stool components are known to inhibit PCR amplifications, $0.03 \mathrm{~g}, 0.08 \mathrm{~g}, 0.2 \mathrm{~g}$, and $0.5 \mathrm{~g}$ of stool at a concentration of $50 \mathrm{HK}-9$ trophozoites per milligram were extracted and the DNA was amplified as described. The optimal amount of stool was found to be between $0.08 \mathrm{~g}$ and $0.2 \mathrm{~g}$. Using a sample size of $0.1 \mathrm{~g}$, the detection limit was found to be one trophozoite per milligram of stool when $1,000,300$, 100,30 , and 10 trophozoites, respectively, were tested in a $0.1-\mathrm{g}$ stool sample.

Specificity of the PCR primers. The primer pair EH-1 and EH-2 is complementary to both pathogenic and nonpathogenic sequences with the exception of EH-2, in which the pathogenic and the nonpathogenic forms differ at the fourth base. The EH-2 primer was therefore constructed two-fold degenerately, i.e., as a mixture with half corresponding to the pathogenic sequence and the other half corresponding to the nonpathogenic sequence. The first, the preamplification PCR with EH-1 and EH-2, is followed by two additional PCRs, each of which is specific for either the pathogenic or the nonpathogenic sequence. The primers used for these reactions are located downstream of EH-1 and EH-2, making this a nested PCR to increase sensitivity. The two primer pairs used in these second PCRs were constructed in such a way that mutations specifying pathogenic or nonpathogenic forms are placed near the $3^{\prime}$ end to increase specificity at the same time. This is in agreement with an earlier observation that an absolute requirement for PCR primers to function is a perfect match of at least two bases at the $3^{\prime}$ end. ${ }^{10}$ The primer pair EHP-1 and EHP-2, as well as the primer pair EHN-1 and EHN-2, were found to selectively amplify pathogenic or nonpathogenic $E$. histolytica DNA, respectively (Figure 1).

Verification of the PCR products by restriction endonuclease digest. The results of the PCR amplifications were confirmed by a re- 


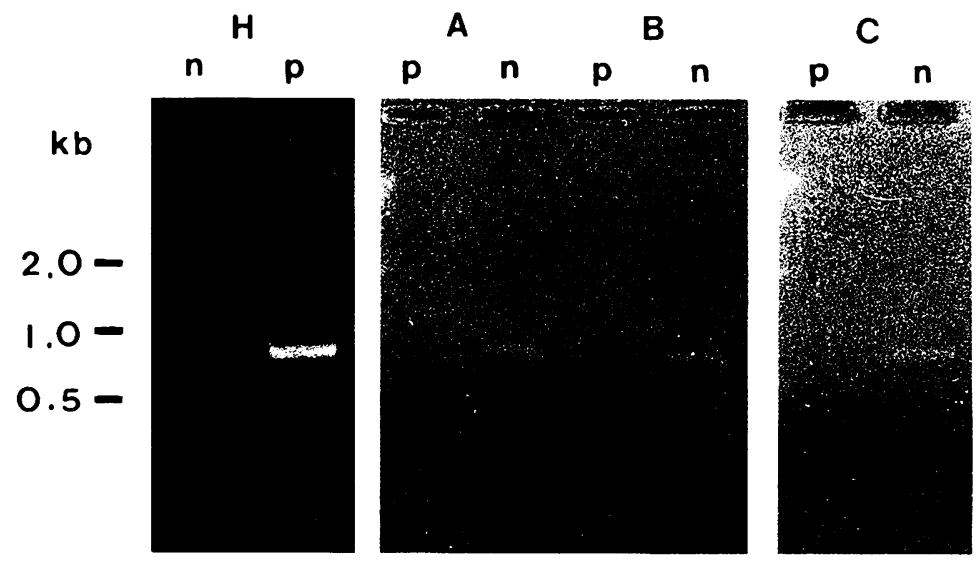

FIGURE 1. Polymerase chain reaction (PCR) amplification products of cultured trophozoites from the pathogenic strain HK-9 of Entamoeba histolytica $(\mathrm{H})$ and three nonpathogenic patient specimens $(\mathrm{A}, \mathrm{B}$, and $\mathrm{C})$. The second, nested PCR shown was performed with the primer pair EHP-1 and EHP-2 (p) or with the primer pair $\mathrm{EHN}-1$ and $\mathrm{EHN}-2(\mathrm{n})$, respectively. $\mathrm{kb}=$ kilobases.

striction endonuclease double digestion with DraI and Sau 96 I. The Dral restriction site is common to both forms and confirms the presence of $E$. histolytica DNA by producing a 0.55 $\mathrm{kb}$ band. The remaining $0.35-\mathrm{kb}$ fragment con-

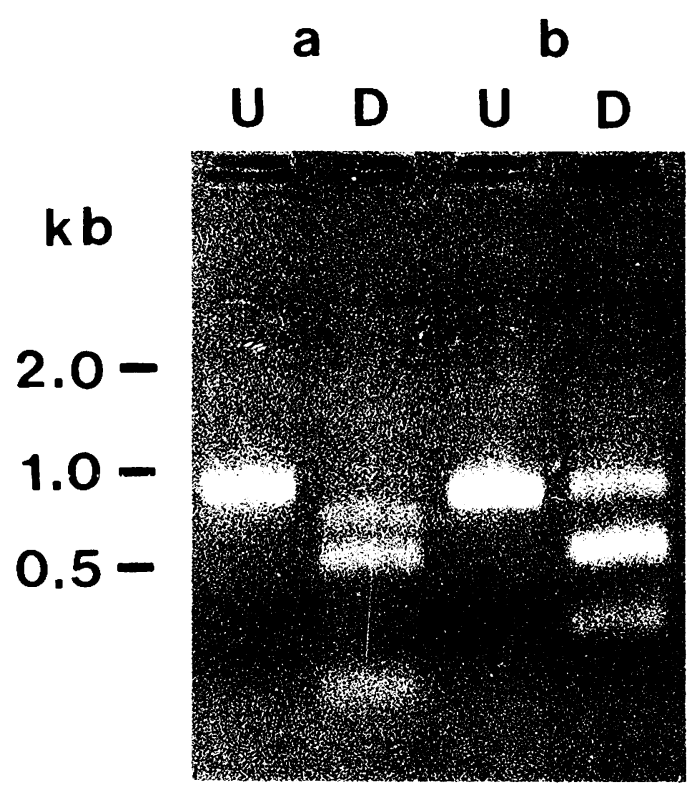

FIGURE 2. Restriction endonuclease digestions of the products from polymerase chain reactions reactions as described in Figure 1, a, nonpathogenic Entamoeba histolytica DNA. b, pathogenic HK-9 DNA. U = undigested; $\mathrm{D}=$ digested with $\operatorname{Dra} \mathrm{I}$ and $S a u 96 \mathrm{I} . \mathrm{kb}=$ kilobases. tains a $S a u 96$ I restriction site $0.2 \mathrm{~kb}$ from the $3^{\prime}$ end of the nonpathogenic sequence with a base mutation in the pathogenic form. Therefore, the pathogenic DNA exhibits characteristic bands of $0.55 \mathrm{~kb}$ and $0.35 \mathrm{~kb}$, usually with some of the undigested $0.9-\mathrm{kb}$ band remaining. The nonpathogenic DNA yields a band of $0.55 \mathrm{~kb}$ and a confluent double band of 0.15-0.2 kb, often with a partial digestion product of $0.7 \mathrm{~kb}$ (Figure 2).

\section{DISCUSSION}

The protocol described provides a method to sensitively and selectively detect and differentiate between pathogenic and nonpathogenic $E$. histolytica DNA directly from stool specimens without the need for prior cultivation. Apart from the often unsuccessful and time-consuming cultivation attempts, possible misdiagnoses by one strain displacing another in mixed infections are being avoided. The method is fast and simple because all extraction steps can be performed at room temperature in a $1.5-\mathrm{ml}$ microcentrifuge tube format. Neither ice nor refrigeration is required. There is no precipitation step, eliminating problems with small amounts of DNA. No laborious hybridizations or the use of radionucleotides are required. The whole procedure can be performed in one day.

Financial support: This work was supported by the Friedrich-Baur-Stiftung (Nr. 13/93) and by the Akademie fur Tiergesundheit e.V. 
Authors' address: Sylvia Katzwinkel-Wladarsch, Thomas Loscher, and Heinz Rinder, Department of Tropical Medicine and Infectious Diseases, University of Munich, Germany.

Reprint requests: Heinz Rinder, Department of Tropical Medicine and Infectious Diseases, University of Munich, Leopoldstrasse 5, 80802 Munich, Germany.

\section{REFERENCES}

I. Sargeaunt PG, Williams JE, 1978. The differentiation of invasive and non-invasive Entamoeba histolytica by isoenzyme electrophoresis. Trans $R$ Soc Trop Med Hig 72: 519-521.

2. Diamond LS, Clark CG, 1993. A rediscription of Entamoeba histolytica Schaudinn, 1903 (Emended Walker, 1911) separating it from Entamoeba dispar Brumpt. 1925. J Euk Microbiol 40: 340-344.

3. Tannich E, Bruchhaus I, Walter RD, Horstmann RD, 1991. Pathogenic and nonpathogenic Entamoeba histolvtica: identification and molecular cloning of an iron-containing superoxide dismutase. Mol Biochem Parasitol 49: 61-72.

4. Clark CG, Diamond LS, 1991. Ribosomal RNA genes of "pathogenic" and "nonpathogenic"
Entamoeba histolvtica are distinct. Mol Biochem Parasitol 49: 297-302.

5. Tachibana H, Ihara S, Kobayashi S, Kaneda Y, Takeuchi T, Watanabe Y, 1991. Differences in genomic DNA sequences between pathogenic and nonpathogenic isolates of Entamoeba histolytica identified by polymerase chain reaction. $J$ Clin Microbiol 29: 2234-2239.

6. Acuna-Soto R, Samuelson J, de Girolami P, Zarate L, Millan-Velasco F, Schoolnik G, Wirth D, 1993. Application of the polymerase chain reaction to the epidemiology of pathogenic and nonpathogenic Entamoeba histolytica. Am J Trop Med Hyg 48: 58-70.

7. Diamond LS, 1968. Techniques of axenic cultivation of Entamoeba histolytica Schaudinn, 1903 and E. histolytica-like amebae. J Parasitol 54: 1047-1056.

8. Bretagne S, Guillou JP, Morand M, Houin R, 1993. Detection of Echinococcus multilocularis DNA in fox faeces using DNA amplification. Parasitology 106: 193-199.

9. Sambrook J, Fritsch EF, Maniatis T, 1989. Molecular Cloning: A Laboratory Manual. Second edition. Cold Spring Harbor, NY: Cold Spring Harbor Press.

10. Sommer R. Tautz, D, 1989. Minimal homology requirements for PCR primers. Nucleic Acids Res 17: 6749. 